\title{
Boosting Students' Confidence and Skill in Writing Using Social Media
}

\author{
Rizky Lutviana*, Siti Mafulah \\ English Education Department \\ Universitas PGRI Kanjuruhan Malang \\ Malang, Indonesia \\ *lutviana.rizky@unikama.ac.id, siti_mafulah@unikama.ac.id
}

\begin{abstract}
Social media are recently used beyond communication, it is also used as a tool to learn foreign language by posting content written in English. The purpose of this study is to explore the use of social media in learning writing. Problems faced by students in learning writing is the ability to generate idea in writing. This study employed descriptive qualitative research. The subjects were 30 EFL students who took basic writing course. Instrument used was interview, observation, and questionnaire. To gain the data, social media are used as a tool to develop students' writing as well as to publish their writing. Students made outline, draft, and revision in WhatsApp group. They received instant feedback from both peers and teacher. They publish their writing on WhatsApp Group. Result indicated that WhatsApp is effective to be used for asynchronous learning in which writing project needs extra time. WA could improve students' writing skill because it builds good learning community in which students learn by developing idea and content by sharing work and comments. In addition, WA could make students confident in writing because they had place to present their work and learn to appreciate it.
\end{abstract}

Keywords—social media, writing skill, EFL students

\section{INTRODUCTION}

During pandemic covid-19 it is mandatory to continue teaching and learning activities, one of which through distance learning. Several options of online learning are offered to the teacher and student both in the form of synchronous or asynchronous modes, such as freely available online learning flat form, for example Edmodo, google classroom, schoology, etc., Moodle LMS, and social media.

Several studies prove the benefit of social media in learning, as it can be used effectively to share information [1], improve students' interest in learning vocabulary, useful for academic purpose and supplement face-to-face learning [2], improve learning and literacy practice [3], developed critical thinking [4], and especially improve students' English proficiency [5]. These studies indicate that social media is suitable to be used in teaching and learning foreign language. Social media enable students to practice English in use [6], especially when communicating with teacher or their classmates.
This present study explores the use of social media as a tool in boosting students' confidence and skill in writing. Writing skill is sequential process [7], in the process of writing, collaboration between pairs is needed, especially in giving feedback in editing stage . Social media promote students' engagement as it enables students to work together to meet a common goal [8], in this case to compose a good paragraph of writing.

The background of students in this present study is the first semester of University students majoring in English Education program. The common problem face by freshmen in English Department in writing course is the confidence and the ability to generate idea in writing. Furthermore, teaching freshmen by distance learning presents challenge for the teacher as they have limited chance to have face-to-face interaction due to, mostly by technical problem, thus it is mostly hard for teacher to understand students' behaviour in learning. Teacher needs intense communication with students, and social media is one of the suitable tools.

Developing idea in writing is not only common problem faces by Indonesian students. A study conducted by Seyabi \& Tuzlukova indicated that 317 University students in Oman mostly had problem in writing a correct English sentence; putting the ideas together in a coherent way; choosing the right vocabulary to express ideas and having ideas about the suggested topics and deciding how to start an essay/paragraph [9]. Adas \& Bakir [10] noted that blended learning can be a solution to the writing problem since it allows the teaching and learning writing less monotonous.

Furthermore, current practice in teaching writing trough distance learning is mostly used blog as a learning tool (such as in (Nepomuceno [11], Artvianti [12], Shana \& Abulibdeh [13], Kuimova \& Zvekov [14], and Mabuan [15]). However, the use of social media in teaching writing remain unexplored since most previous studies on the use of social media to teach writing focus on discovering the role of social media to assist learning and limited studies about the used of social as a medium to teach and learn English skill, particularly writing. 
Salikin et al. [16] investigated the effectiveness of social media, particularly Facebook and WhatsApp in teaching writing to 64 EFL university students majoring in English. The sample were chosen randomly. The researcher compared pretest and post-test score of the experiment and control group to find the effectiveness of social media in teaching writing. The experimental group were taught using Facebook while control group using WhatsApp. Instrument to collect the data were writing test, interview, and observation. The topic for writing test is descriptive text about occupation, environment, daily activity, environment. Students' writing was assessed based on its content, organization, vocabulary, language use and mechanics. Students in both control and experimental class received 6 meetings lesson that included theoretical lesson for 40 minutes and practice 50 minutes to practice writing in Facebook (for experimental class) and WhatsApp (for control class). It is found that the use of social media did not significantly improve the students' writing skill since the main score did not show the significant improvement of their writing skill. There were some specific factors that hindered the students; achievement in writing descriptive text.

Wil et al. [17] conducted survey study to investigate the use of social media to assist writing skill of 40 secondary school students in Malaysia. Instrument used to gather the data was questionnaire in the form of combination between structured and open-ended question. It is found that most students (45\%) students used social media for 16-20 hours. Instagram and WhatsApp are the most widely used application. However, most students used social media to communicate with friends and family rather than to learning. In contrast, most students agree that social media is effective tool to improve their English because social media assists respondents to write better by interacting through visual communication, improve their communication skills by learning new languages and read online sample essays. This is because social media is not only interesting for learning but it is also loaded with important information, as a fun and interactive medium.

Arif [18] conducted survey to discover the use of social media in learning English. The participants were 67 third semester students. The instrument used to collect the data was questionnaire and semi structured interview. It is found that among many social media, Facebook and Instagram is the most widely used. Most students agree that social media plays important role in supporting students' learning English. In this case social media motivate them to practice language in use, most students use English when communicating in social media.

Different from the previous studies, this present study aimed at discovering the use of social media, especially WhatsApp as a tool to teach writing skill. In the previous studies the social media were used for many purposes besides teaching and learning, in this present study students received lesson, done task, and develop writing skill using WhatsApp.

\section{Methodology}

This study employed descriptive qualitative method with the participant 30 first semester of EFL students majoring in English education. Students received 5 weeks' lesson via
WhatsApp with the duration 200 minutes a week. The lessons include basic writing skill including language (grammar), as well as practice in the stages of writing from outlining, drafting, revising, and publishing to train developing idea, organizing idea, and correct use of word. Instruments used to collect the data were (1) questionnaire to measure students, attitude toward the use of WhatsApp as a tool in learning, (2) interview to get deeper information about the reason, and (3) observation to measure students' active participation and confidence during learning. To gain the data, social media are used as a tool to develop students' writing as well as to publish their writing. The data were students' writing and participation on WAG.

\section{FINDINGS AND DISCUSSIONS}

\section{A. WhatsApp as a Tool to Teach and Learn Writing}

The use of WhatsApp as a tool to teach and learn writing can be described as how teacher and students use it for learning. In this case, teacher created WhatsApp Group (WAG) which consist of all students. To manage students, WAG needs administration staff. The teacher and captain of class became the administration staff.

Teaching and learning writing via WAG happened as it was scheduled (every Wednesday, at 8:40 to $12: 00 \mathrm{pm}$ ), the order of lesson resembled the order of face-to-face classroom in which at the beginning teacher greeted students, stated the objective of the lesson. Then, during teaching and learning, teacher gave task, in this case teacher gave task to make outline about "My favorite Things". Teacher shared the material including module that consisted summary of material and worksheet consisted example and guidance to develop outline on WAG. Next, students uploaded their outline on WAG, teacher gave student task to give feedback to their friend's outline. The feedback should include suggestion on the content as well as language (grammar and vocabulary, see Figure 1).

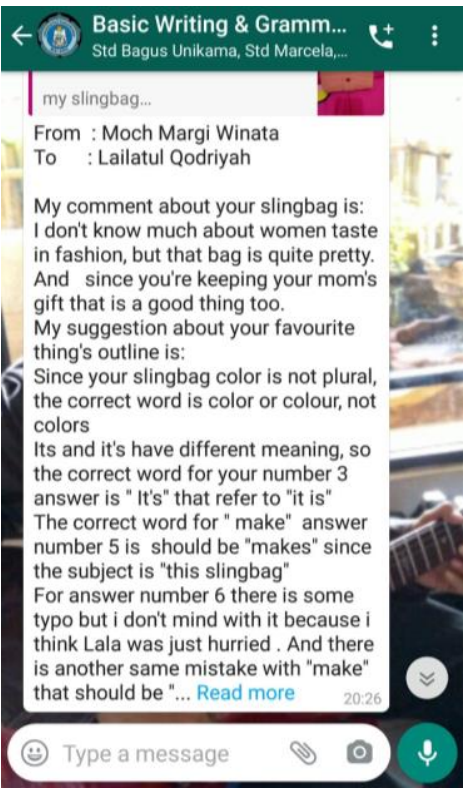

Fig. 1. Student's corrective feedback. 
As we can see in Figure 1. Student's Corrective Feedback, the activity of giving feedback took long time, exceed the regular schedule. So, teacher instructed students to give feedback on their free time. It is case WAG was used as asynchronous learning. After giving feedback student fill in the questionnaire about the practical aspect of WAG on learning.

Table 1 . The Practicality of WAG, summarized the result of questionnaire about students' perception on the use of WAG.

TABLE I. THE PRACTICALITY OF WAG

\begin{tabular}{|c|c|c|c|c|c|}
\hline \multirow[t]{2}{*}{ No } & \multirow[t]{2}{*}{ Question } & \multicolumn{4}{|c|}{ Responses (in percentage \%) } \\
\hline & & $\begin{array}{c}\text { Strongly } \\
\text { agree }\end{array}$ & Agree & Disagree & $\begin{array}{l}\text { Strongly } \\
\text { disagree }\end{array}$ \\
\hline 1 & $\begin{array}{l}\text { WAG is easy to } \\
\text { access even when } \\
\text { you have low internet } \\
\text { connection. }\end{array}$ & 40 & 43.3 & 13.3 & 3.3 \\
\hline 2 & $\begin{array}{lr}\text { Sharing } & \text { and } \\
\text { downloading file, } \\
\text { material, assignment, } \\
\text { picture, and video are } \\
\text { easier and more } \\
\text { reachable } \\
\text { WAG than other } \\
\text { applications. }\end{array}$ & 26.7 & 73.3 & 0 & 0 \\
\hline 3 & $\begin{array}{l}\text { Learning via WAG is } \\
\text { flexible (can be done } \\
\text { in any condition). }\end{array}$ & 43.3 & 43.3 & 6.7 & 6.7 \\
\hline 4 & $\begin{array}{l}\text { Facilities in WAG } \\
\text { are useful to support } \\
\text { my learning activity. }\end{array}$ & 20 & 66.7 & 6.7 & 6.7 \\
\hline 5 & $\begin{array}{l}\text { Learning writing via } \\
\text { WAG is effective. }\end{array}$ & 20 & 63.3 & 16.7 & 0 \\
\hline 6 & $\begin{array}{l}\text { Learning writing via } \\
\text { WAG is fun. }\end{array}$ & 20 & 60 & 20 & 0 \\
\hline
\end{tabular}

Referring to Table 1. The Practicality of WAG, based on the result of questionnaire, most students agreed that WhatsApp is convenient and handy, as $83.3 \%$ students agreed that WAG is easy to access even when they had low internet connection. Most students live in the area with low internet connection. Based on the observation, 96\% students were online on WA during lesson. Only 1 student cannot access the lesson due to extreme low internet connection. Besides, WA is handy can be accessed in any flat form either hand phone or laptop. This made learning can be done in any situations $(87 \%$ students agreed).

Moreover, WA could be a good tool for learning since most students felt that learning writing via WAG was effective $(83.3 \%)$, and fun $(80 \%)$. Students thought that WA was beneficial for learning because they felt easy to share and download learning materials (100\%). In addition, most students felt that facilities in WAG were useful to support their learning activity $(86.7 \%)$. Based on the result of interview, facilities on WA that most students thought was useful in writing included group chat, attach file, and voice note.

Group chat because they can be read and understood and can spot errors in writing or grammar

Voice note and group chat. Because I can hear and try to speak good pronunciation so my friends and lecture can hear me too and I can improve my writing skill trough every message from my friends.

Social media such as WhatsApp allows social interaction both between teacher and student and between student and student. Learning in this era put much emphasis on the learning process through interaction using technology as the platform [19]. Besides, WhatsApp is handy and convenient to be used in various platform such as laptop, personal computer, android phones, and iPhone [20]. WhatsApp is free and light, it does not require strong internet connection. Therefore, it can be reached by students even in remote area.

\section{B. WA and Students' Writing Skill}

In order to discover how WA, improve students' writing skill, online interview via zoom meeting was conducted. Table 2 presented the interview guide.

\section{TABLE II. INTERVIEW GUIDE}

\begin{tabular}{|c|c|c|}
\hline No & Question & Responses \\
\hline 1 & $\begin{array}{l}\text { How do you } \\
\text { develop your idea } \\
\text { in writing during } \\
\text { learning activity } \\
\text { in WAG? }\end{array}$ & $\begin{array}{l}\text { - I'll try to read and understand about the } \\
\text { matter that my teacher shared on WAG and } \\
\text { when i don't understand with the matter i'll } \\
\text { ask the teacher on the group. } \\
\text { - My idea is often from my friend or } \\
\text { situation around me. } \\
\text { - Understand the reading / material } \\
\text { presented by the lecturer first, after that I } \\
\text { can develop my ideas in the form of } \\
\text { writing / voice messages on the whats app } \\
\text { group. } \\
\text { I will thinking about it for a moment and if } \\
\text { i can't get the idea yet, i will read the } \\
\text { sentence that i have to respond in many } \\
\text { time until i get the idea. And also i read } \\
\text { others sentence. } \\
\text { It is very easy to get out of WhatsApp } \\
\text { rather than others if we want to find } \\
\text { references in other media. and it's easy to } \\
\text { exchange opinions with friends. } \\
\text { - I can correct my word and sentence trough } \\
\text { seeing my friends and teacher sentence. } \\
\text { - Often the communication with My friends } \\
\text { or Lectureship. } \\
\text { by looking at a friend's assignment } \\
\text { heard lots of lecturers' instructions } \\
\text { - Share in group }\end{array}$ \\
\hline 2 & $\begin{array}{l}\text { What do you think } \\
\text { about the use of } \\
\text { WAG to develop } \\
\text { your outline, is it } \\
\text { effective? }\end{array}$ & $\begin{array}{l}\text { - For learning materials / materials I am very } \\
\text { satisfied that it can be done in the WAG } \\
\text { app, but what needs to be improved is the } \\
\text { response from students / lecturers in } \\
\text { learning or assignments. For example, I } \\
\text { often ask one of the lecturers from several } \\
\text { existing courses, but sometimes I have to } \\
\text { wait a long time and I am a little confused } \\
\text { when my friends ask me what the } \\
\text { assignment is, when the deadline and what } \\
\text { is the collection through. } \\
\text { I think yes. Because I can learn from my } \\
\text { friends and teacher pronunciation trough } \\
\text { voice note and my grammar, sentence from } \\
\text { them. }\end{array}$ \\
\hline
\end{tabular}


Table 2. Cont.

\begin{tabular}{|c|c|c|}
\hline & & $\begin{array}{l}\text { - less effective, because sometimes there are } \\
\text { unreadable chats and sometimes while } \\
\text { listening to the material, suddenly someone } \\
\text { calls } \\
\text { - } \\
\text { agree, because if you use wa the network is } \\
\text { easy } \\
\text { - } \begin{array}{l}\text { I think it is more effective, because with } \\
\text { WAG we can know our deficiency. And } \\
\text { we can improve our work to the future. }\end{array} \\
\end{array}$ \\
\hline 3 & $\begin{array}{l}\text { What do you like } \\
\text { about learning } \\
\text { writing via WAG? }\end{array}$ & $\begin{array}{ll}\text { - } & \text { not complicated } \\
\text { - } & \text { not showing my face } \\
\text { - } & \text { I can see my friend's work and develop my } \\
\text { own/improve my own } \\
\text { - } & \text { Little bit confusing, but there is something } \\
\text { fun with teacher's materials. } \\
\text { - } & \text { Make me focus on writing } \\
\text { - } & \text { Lecturers can help me directly about what } \\
\text { my writing is wrong and what is right. and } \\
\text { can discuss with friends about the learning } \\
\text { that will take place. } \\
\text { - I can exchange ideas well with my friends } \\
\text { because sometime i doing it immediately i } \\
\text { feel little bit nervous } \\
\text { - can continue to compete with my friends } \\
\text { although sometimes i feel less confident }\end{array}$ \\
\hline 4 & $\begin{array}{l}\text { What lesson do } \\
\text { you get when you } \\
\text { learn writing via } \\
\text { WhatsApp? }\end{array}$ & $\begin{array}{l}\text { - I can understand immediately when } \\
\text { reading the feedback from my friends to } \\
\text { other friends. and I can immediately } \\
\text { correct my writing mistakes. } \\
\text { - lesson this week as well as last week, I will } \\
\text { find it easier to find learning materials } \\
\text { today and last week } \\
\text { - Many Learning that } 1 \text { find in WAG.the } \\
\text { prime is at the lecture proccess.the } \\
\text { example : can writing the article,and make } \\
\text { conversation with my friend. } \\
\text { - my vocabulary increased even a little. } \\
\text { Hehe } \\
\text { - I know about grammar well than before. } \\
\text { - more sensitive to vocabulary } \\
\text { - it makes it easier for me when I want to re- } \\
\text { learn the previous lesson, because every } \\
\text { day I always open WhatsApp }\end{array}$ \\
\hline
\end{tabular}

Related to the first question, teacher's explanation, instruction, and the availability of materials were the factors contribute to the effectiveness of learning writing using WA. The facility of sharing file enables students to get materials including lecture in the form of PPT or Video. Besides, teacher can give instruction orderly in WAG and can be seen easily by most students. Teacher could also repeat the instruction when students did not understand it.

Communication is very important in learning [21]. WA enables communication between teacher and student as well as between students and their classmates. Learning happens when there is intense interaction [22] between teacher and students. Besides, WA made good learning community since it inspired students to develop idea and content by sharing work and comments. Sharing work through WA helped them to improve the idea and organization in writing.
Relaying on the second and third question, WA could develop students' writing skill by doing and presenting task in WAG discussion. Students' build idea in writing by feedback given by students and teacher. Students knew their lack on writing and find the solution to improve it. Additionally, seeing other friend's work will also give them idea in writing. Besides developing idea, students also learn to improve their language accuracy in writing, especially grammar and writing.

\section{WA and Students' Confidence}

Confidence is one of important factors contribute to the success on learning. Table 3 presented students' confidence during learning using WA.

TABLE III. STUdents' CONFIDENCE

\begin{tabular}{|c|c|c|c|c|c|}
\hline \multirow[t]{2}{*}{ No } & \multirow[t]{2}{*}{ Question } & \multicolumn{4}{|c|}{ Responses } \\
\hline & & $\begin{array}{c}\text { Strongly } \\
\text { agree }\end{array}$ & Agree & Disagree & $\begin{array}{c}\text { Strongly } \\
\text { disagree }\end{array}$ \\
\hline 1 & $\begin{array}{lr}\text { I } & \text { often } \\
\text { participate } & \\
\text { during } & \text { class } \\
\text { discussion } & \text { via } \\
\text { WAG } & \end{array}$ & 23.3 & 70 & 6.7 & 0 \\
\hline 2 & $\begin{array}{l}\text { I am confident } \\
\text { posting my work } \\
\text { in WAG }\end{array}$ & 30 & 60 & 10 & 0 \\
\hline 3 & $\begin{array}{l}\text { I am confident } \\
\text { participating in } \\
\text { WAG discussion }\end{array}$ & 23.3 & 70 & 6.7 & 0 \\
\hline 4 & $\begin{array}{l}\text { I am happy when } \\
\text { my friends and } \\
\text { lecturer read my } \\
\text { writing in WAG }\end{array}$ & 50 & 46.7 & 3.3 & 0 \\
\hline 5 & $\begin{array}{l}\text { I am happy when } \\
\text { my friends and } \\
\text { lecturer } \\
\text { comment my } \\
\text { writing in WAG }\end{array}$ & 36.7 & 63.3 & 0 & 0 \\
\hline 6 & $\begin{array}{l}\text { My friend's } \\
\text { comment and } \\
\text { lecturer's } \\
\text { comment help } \\
\text { me to improve } \\
\text { my writing }\end{array}$ & 53.3 & 46.7 & 0 & 0 \\
\hline
\end{tabular}

Learning writing by WA increased students' confidence since more students participated during class discussion (93\%) regardless their proficiency in language. Students felt positive when presenting their work $(90 \%)$ or participating in discussion $(83.3 \%)$. They liked reading their friends' work, felt entertained. Besides, reviewing their friend's work helped them to be critical. Critical thinking required learning and this motivate them to be improved. Most students were open to receive any suggestion from both friend and lecturer. In addition, students felt confident because they learn to appreciate their friends' work. Most of them were happy when friends and lecturer comment their writing in WhatsApp Group $(100 \%)$.

\section{CONCLUSION}

To sum up, WA provided facility to both synchronous and asynchronous learning. However, in teaching and learning writing WhatsApp is effective to be used for asynchronous 
learning in which writing project needs extra time. Teacher's explanation, instruction, and the availability of materials were the factors contribute to the effectiveness of learning writing using WA. WA could improve students' writing skill because it builds good learning community in which students learn by developing idea and content by sharing work and comments. In addition, WA could make students confident in writing because they had place to present their work and learn to appreciate it.

\section{REFERENCES}

[1] E. Bal and H. Bicen, "ScienceDirect ScienceDirect The purpose of students 'social media use and determining their perspectives on education," Procedia Comput. Sci., vol. 120, pp. 177-181, 2018.

[2] E. Tartari, "The Use of Social Media for Academic Purposes in Student' Learning Process," Acad. J. Interdiscip. Stud., vol. 4, no. 2, pp. 393-398, 2015.

[3] O.G. Stewart, "A critical review of the literature of social media ' affordances in the classroom," 2016

[4] F. Kustijono and R. Zuhri, "The use of Facebook and WhatsApp application in learning process of physics to train students , critical thinking skills The use of Facebook and WhatsApp application in learning process of physics to train students " critical thinking skills," 2018 .

[5] S.M.F. Haque, N. Mofareh, and A. Salem, "Social Media in EFL Context: Attitudes of Saudi Learners," vol. 10, no. 5, pp. 1029-1040, 2019.

[6] V. Li, "Social Media in English Language Teaching and Learning," Int. J. Learn. Teach., vol. 3, no. 2, pp. 148-153, 2017.

[7] A.P. aul Johnson, Teaching Reading and Writing. New York: Rowman and Littlefield Education, 2008.

[8] R. Faizi, "Exploring the Potential Benefits of Using Social Media in Education," pp. 50-53.

[9] F. Al Seyabi and V. Tuzlukova, "Writing Problems and Strategies: An Investigative Study in the Omani School and University Context," vol. 3, no. November, pp. 37-48, 2014
[10] D. Adas and A. Bakir, "Writing Difficulties and New Solutions: Blended Learning as an Approach to Improve Writing Abilities $\mathrm{PhD}$ in teaching English Language Methods , AL-Quds Open University ," vol. 3 , no. 9,2013

[11] M.M. Nepomuceno, "Writing Online: Using Blogs as an Alternative Writing Activity in Tertiary ESL Classes Far Eastern UniversitySilang," vol. 5, no. December, pp. 92-105, 2011.

[12] E.I.D. Artvianti, "The Use Of Classroom Blog In Teaching Writing To Junior," vol. 1, no. 1, pp. 59-67, 2013.

[13] Z.A. Shana and E.S. Abulibdeh, "Engaging Students through Blogs: Using Blogs to Boost a Course Experience," pp. 30-38, 2010.

[14] M.V. Kuimova and O.D. Zvekov, "Blogs as a means to enhance writing skills in EFL classes,” Int. J. Emerg. Technol. Learn., vol. 11, no. 4, pp. 157-160, 2016.

[15] R.A. Mabuan, "Using Blogs In Teaching Tertiary Esl Writing," vol. 6, no. 2,2018

[16] H. Salikin, S. Zulfiqar, and B. Tahir, "The Social Media-Based Approach in Teaching Writing at Jember University , Indonesia," vol. 7 , no. 3, pp. 46-57, 2017.

[17] C. Surhaizai, C. Wil, M. Yunus, and A. Suliman, "The Use of Socia Media to Assist Writing Skills among Secondary Pupils The Use of Social Media to Assist Writing Skills among Secondary Pupils," vol. 8 , no. 3, pp. 224-236, 2019.

[18] T.Z.Z. Al Arif, "The Use of Social Media for English Language Learning: An Exploratory Study of EFL University Students," vol. 3, no. 2, pp. 224-233, 2019.

[19] P. Kufre and E. Abe, "Effectiveness of Whatsapp as a collaborative tool for learning among undergraduate students in university of Uyo , Akwa Ibom state," vol. 2, no. 5, pp. 43-46, 2017.

[20] S. Gon and A. Rawekar, "Effectivity of E-Learning through Whatsapp as a Teaching Learning Tool," vol. 4, no. June, pp. 19-25, 2017.

[21] A. Khan, S. Khan, S. Zia-Ul-Islam, and M. Khan, "Communication Skills of a Teacher and Its Role in the Development of the Students' Academic Success,” J. Educ. Pract., vol. 8, no. 1, pp. 18-21, 2017.

[22] R.M. Bernard, E.M. Bures, E. Borokhovski, and R. Tamim, "Interaction in Distance Education and Online Learning :," 2010. 